
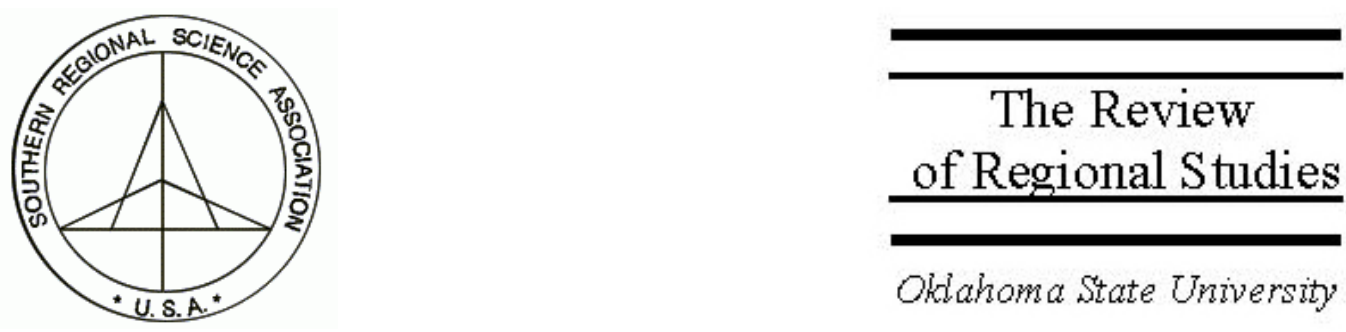

\title{
The Impact of Lotteries on State Education Expenditures: Does Earmarking Matter?
}

\author{
Louis Pantuosco \\ College of Business Administration, Winthrop University, Rock Hill, SC 29733, \\ e-mail: pantuoscol@winthrop.edu \\ William Seyfried \\ Crummer Graduate School of Business, Rollins College, Winter Park, FL 32789, \\ e-mail:wseyfried@rollins.edu \\ Robert Stonebraker \\ College of Business Administration, Winthrop University, Rock Hill, SC 29733, \\ e-mail: stonebrakerr@winthrop.edu
}

\begin{abstract}
In this paper, we estimate the impact of earmarking lottery revenue to education as opposed to filtering lottery revenue through a state's general fund. A unique facet of this investigation is the comparison of states with lottery revenue earmarked for spending on K-12 education and states with lotteries for general funds. This approach enables us to investigate the effect of state lottery revenues on education and other budgetary components in a more controlled environment by mitigating lottery preference differences across states. Consistent with previous research, we find that earmarking lottery proceeds for K-12 education has little or no impact on actual state K-12 funding. We also find that lottery revenue does seem to increase $\mathrm{K}-12$ funding in states that deposit the revenues into their general funds.
\end{abstract}

Keywords: Lotteries; Education spending

JEL classification: H75; H72 


\section{INTRODUCTION}

Lotteries have been touted as a solution to education funding woes since 1967. Even states with strong conservative religious traditions have jumped on the bandwagon. Former South Carolina Governor Jim Hodges proudly proclaimed that the 2000 referendum approving a lottery in his state was "a home run for education"(Hodges 2001). After an education lottery was narrowly approved in neighboring North Carolina in 2005, Governor James Easley trumpeted the vote as "a win for our schoolchildren,"(Bolton 2005) and newly installed North Carolina Lottery Commissioner Tom Shaheen vowed to lead the charge "to raise as much money as we possibly can for all the great education programs" around the state (Robertson 2005). However, lottery revenues potentially are fungible. Even if state legislatures earmark lottery revenues for education, government officials could easily shift monies previously used for education to other budget areas. In addition, dollars spent on lottery tickets could crowd out other spending and reduce general sales tax revenue.

Do states honor their commitments to supplement education with lottery revenue? Many researchers answer that question negatively. Borg and Mason (1990) find that "education" lotteries had no significant impact on educational funding. They conclude that "lottery earmarking proponents should reconsider whether pre-designating recipients of lottery revenues is really in the best interest of the entity concerned." Subsequent research verifies the fungibility of education lottery funds, yet state governments continue to implement lotteries and sell them on the precept of educational enhancement.

Once adopted, legislators recognize the benefits of sustaining a lottery. Lotteries increase the government's revenue base and behave as voluntary taxes, allowing states to increase spending without impacting debt or tax rates. Even legislators who oppose lotteries on economic or moral grounds often are trapped in a classic prisoner's dilemma. Adopting a lottery can be a dominant strategy in the game to export taxes to neighboring states (Erekson et al. 2002). Indeed, many South Carolinians rationalized their support for a lottery by claiming that it would stop citizens from traveling across state lines to buy Georgia lottery tickets and would also attract tax dollars from North Carolinians. Following suit, North Carolinians approved a lottery to inhibit their citizens from crossing into South Carolina and Virginia.

This study extends the literature in two ways. First, we use a different methodology to estimate the impact of lotteries on state spending. Past researchers have compared education spending in states that earmark lottery revenue for education to that in other states. Others have compared pre-lottery and post-lottery education expenditures. Instead, we compare lottery states that earmark the funds for K-12 education to lottery states that funnel the revenue through their general fund. We then estimate the impact of lotteries on state spending for K-12 education, higher education, welfare, and highways and compare the effects in "lottery-for-education states" to those in "lottery-for-general fund states." 
Second, we develop a framework in which legislators might treat earmarking either as a complement or a substitute for actual funding. If the two are complements, earmarking lottery revenues for education should increase actual allocations. Earmarking will raise the political return to legislators for K-12 spending and prompt them to budget additional monies. On the other hand, a highly visible education lottery might convince ill-informed voters that educational priorities are being addressed, irrespective of how actual monies flow. If so, earmarking could mollify education supporters while legislators divert revenues to reward other constituents.

We find that lottery revenue rarely has a significant impact on K-12 spending in our sample of states that earmark the revenue for that purpose. Yet, in our sample of states that do not earmark, lottery revenue typically does increase the growth of K-12 spending.

\section{LITERATURE REVIEW}

The proliferation of state lotteries has stimulated a wide array of research. ${ }^{1}$ Studies have shown that states adopt lotteries for a variety of reasons, from bandaging fiscal shortfalls (Mikesell and Zorn 1986) to competing with neighbors (Caudill et al. 1995; Garrett and Marsh 2002; Tosun and Skidmore 2004). After lotteries are functioning, the focus shifts from adoption to the horizontal and vertical equity issues of the game. Studies have found lotteries to be regressive (Brinner and Clotfelter 1975; Clotfelter and Cook 1990; Hansen, Miyazaki, and Sprott 2000). Lower income households pay a disproportionately higher percentage of the voluntary tax and receive a disproportionately lower percent of the benefits (Borg and Mason 1988; Rubenstein and Scafidi 2002).

In an effort to legitimize lotteries and downplay their regressive nature, law makers have recently begun earmarking lottery revenue for education: a popular program perceived to benefit lower-income constituents. In the past 10 years, 10 states either have adopted "education" lotteries or enacted legislation to distribute a percentage of their lottery profits directly to education. However, lottery funds are potentially fungible and may not be going to their intended target. The general consensus is that earmarking lottery revenue for education has little or no impact on education budgets. When the lottery funds flow in, legislators react by shifting other funds out of education and into different areas of the budget.

Spindler (1995) focused on elementary and secondary education spending in seven lottery-for-education states and found mixed results. Lotteries added funds for education in some states but not in others. For the three states that overlap our sample, he found that lottery funds were fungible in New Hampshire and Michigan but not very fungible in Ohio. However, Garrett (2001), who also analyzed the impact of the Ohio lottery, concluded that lottery revenues did not lead to increases in education expenditures and that

\footnotetext{
${ }^{1}$ David Vroman began the debate with his study of the New York lottery, which was published in the National Tax Journal in 1976.
} 
"state and lottery officials are not being entirely accurate when they advertise that the lottery has helped education."

Borg and Mason (1990) analyzed pre-and-post lottery education spending within five lottery-for-education states and seven non-lottery states. In the three states that overlap our survey, they concluded that earmarking lottery funds for education had not benefited education in the lottery-for-education states of New Hampshire, Illinois, and Michigan. In fact, after controlling for inflation and enrollment growth, they found education spending to be flat in New Hampshire and declining in Illinois and Michigan since their lotteries began. They concluded that state governments camouflage their inability to raise sufficient funds for the public school system.

Using Florida as their case study, Stark, Wood, and Honeyman (1993) found that public education became under funded after the inception of the lottery. Interestingly, local expenditures for education were in line with their forecast, but state expenditures were not. Apparently local governments stayed the course, but the state used lottery revenue to substitute for other revenue that would have been dedicated to education. Looking at the community college system in Florida, Summers et al. (1995) reported that lottery funds were accompanied by declines in college expenditures, that the lottery's impact was too small to make a difference in the regression results, and that there was redistribution in the funding sources of community colleges after the lottery was adopted.

Erekson et al. (2002, p.309) expanded the discussion by conducting an inclusive study of all 50 states. Focusing on K-12 expenditures, they found that "states where lotteries contribute to general revenue, whether they earmark revenue for education or not, are allowing lottery funds to substitute for general fund revenues that would have otherwise been used for education." Contrary to other studies, Novarro (2005) concluded earmarking for education positively impacts education spending. Education spending increases by $\$ .79$ for every dollar of lottery profit. Campbell (2003) was also able to find a positive and significant relationship between lottery revenue and local per-pupil K-12 spending in Georgia. However, the practical impact was "negligible."

It's possible that lotteries' insignificant impact on education spending stems from their small and inconsistent effect on total state revenue. Mikesell and Zorn (1986) estimate that revenue from lotteries account for less than two percent of state "general own source" revenue. According to their study, Pennsylvania's lottery generated the highest percent of revenue of any state with 4.4 percent of its funds coming from lottery operations. They added that lottery proceeds fluctuate annually and provide an unstable revenue source for U.S. states.

Although there seems to be a consensus that lottery revenues are fungible, several issues have not been adequately addressed. First, while formal models of lottery adoption have been developed (Caudill et al. 1995; Erekson et al. 1999), authors have not found any models that address lotteries' impact on revenues and subsequent budgetary spending. In other words, if lottery proceeds do not flow into increased K-12 budgets, where do 
they go? Most studies have focused on K-12 expenditures; only Summers et al. (1995) isolated a lottery's impact on higher education. Separating spending for K-12 education, higher education, welfare, and highways provides additional insight into how lottery revenues actually are used. Second, previous researchers supported their findings by estimating the statistical differences between lottery states and non-lottery states, or differences within lottery states pre-and-post the lottery's inception. While there is much value in this, such studies do not attempt to control for potentially important factors that could vary across states and/or across time. Third, little thought has been given to legislative motives for shifting funds.

We address these issues by developing a formal model that allows legislators to allocate lottery revenues in a way that maximizes political support. We then estimate the difference in spending decisions among states that earmark 100 percent of their lottery proceeds to K-12 education and states that allocate lottery revenues to their general funds. This approach enables us to isolate a lottery's relative impact on different types of spending in a more controlled environment.

\section{THEORETICAL MODEL}

While other researchers have used the Stigler-Peltzman framework (Stigler 1971; Peltzman 1976) to consider the adoption of a lottery (Erekson et al. 1999), we extend the approach to consider the impact of lotteries on state spending. Following Peltzman, we assume that legislators want to maximize voter support (S). We posit that:

$$
\mathrm{S}=\mathrm{S}(\mathrm{G}, \mathrm{T})
$$

where $\mathrm{G}$ represents government expenditures and $\mathrm{T}$ is tax revenue. We assume $\mathrm{S}_{\mathrm{G}}>0$ and $\mathrm{S}_{\mathrm{T}}<0$.

To the extent that lotteries enable legislators to increase spending without raising taxes, voter support will rise. However, lotteries can face powerful opposition from groups that oppose state-sanctioned gambling and/or condemn their regressive effects. Rational legislators will adopt a lottery if the marginal gain in voter support from increased spending and/or decreased taxes exceeds the marginal loss in support from implementing the lottery.

Once a lottery is adopted, what division of funds will generate the maximum support? We assume that $\mathrm{G}$ is divided among spending for $\mathrm{K}-12$ education $(\mathrm{K})$, spending for higher education $(\mathrm{H})$, spending for welfare (WF), spending on roads and highways $(\mathrm{R})$, and other miscellaneous spending $(\mathrm{M})$, while tax revenues depend upon the effective tax rate $(\mathrm{t})$. Thus,

$$
\mathrm{S}=\mathrm{S}(\mathrm{K}, \mathrm{H}, \mathrm{WF}, \mathrm{R}, \mathrm{M}, \mathrm{t})
$$

where $\mathrm{S}_{\mathrm{K}}>0, \mathrm{~S}_{\mathrm{H}}>0, \mathrm{~S}_{\mathrm{WF}}>0, \mathrm{~S}_{\mathrm{R}}>0, \mathrm{~S}_{\mathrm{M}}>0$, and $\mathrm{S}_{\mathrm{t}}<0$. 
Assuming a fixed, exogenous amount of lottery revenue $(L)$, legislators face a budget constraint of $\mathrm{G}=\mathrm{T}+\mathrm{L}$ and will maximize the Lagrangian:

$$
\mathrm{S}(\mathrm{K}, \mathrm{H}, \mathrm{WF}, \mathrm{R}, \mathrm{M}, \mathrm{t})+\lambda(\mathrm{K}+\mathrm{H}+\mathrm{WF}+\mathrm{R}+\mathrm{M}-\mathrm{L}-\mathrm{T}(\mathrm{t}))
$$

This gives the familiar first-order condition:

$$
-\lambda=\mathrm{S}_{\mathrm{K}}=\mathrm{S}_{\mathrm{H}}=\mathrm{S}_{\mathrm{WF}}=\mathrm{S}_{\mathrm{R}}=\mathrm{S}_{\mathrm{M}}=-\mathrm{S}_{\mathrm{t}} / \mathrm{T}_{\mathrm{t}}
$$

$\mathrm{S}_{\mathrm{K}}, \mathrm{S}_{\mathrm{H}}, \mathrm{S}_{\mathrm{WF}}, \mathrm{S}_{\mathrm{R}}$, and $\mathrm{S}_{\mathrm{M}}$ are the marginal gains in voter support from increasing spending in the respective budget categories, $S_{t}$ is the marginal gain in support from increasing tax rates (it is negative), and $T_{t}$ is the marginal gain in tax revenue from increasing $t$. Therefore, $S_{t} / T_{t}$ is the marginal change in support from increasing $t$ per dollar of tax revenue raised. In other words, legislators will balance the marginal gain in support per dollar of spending with the marginal loss in support from raising $t$ to obtain those dollars. Figure 1 displays the interactions between lottery revenue and budget decisions.

The figure on the left graphs the relationship between funds available for government spending and tax rates, a traditional Laffer curve, along with legislative indifference curves. Assuming that government revenue equals spending, the figure on the right is the government's budget constraint with the amount of dollars committed to K-12 education on the horizontal axis and the remainder of spending on the vertical axis. Legislative preferences initially generate $G_{1}$ dollars of revenue through a tax rate of $t_{1}$. Of these funds, $\mathrm{K}_{1}$ is spent on $\mathrm{K}-12$ education and $\mathrm{O}_{1}$ is spent on other items.

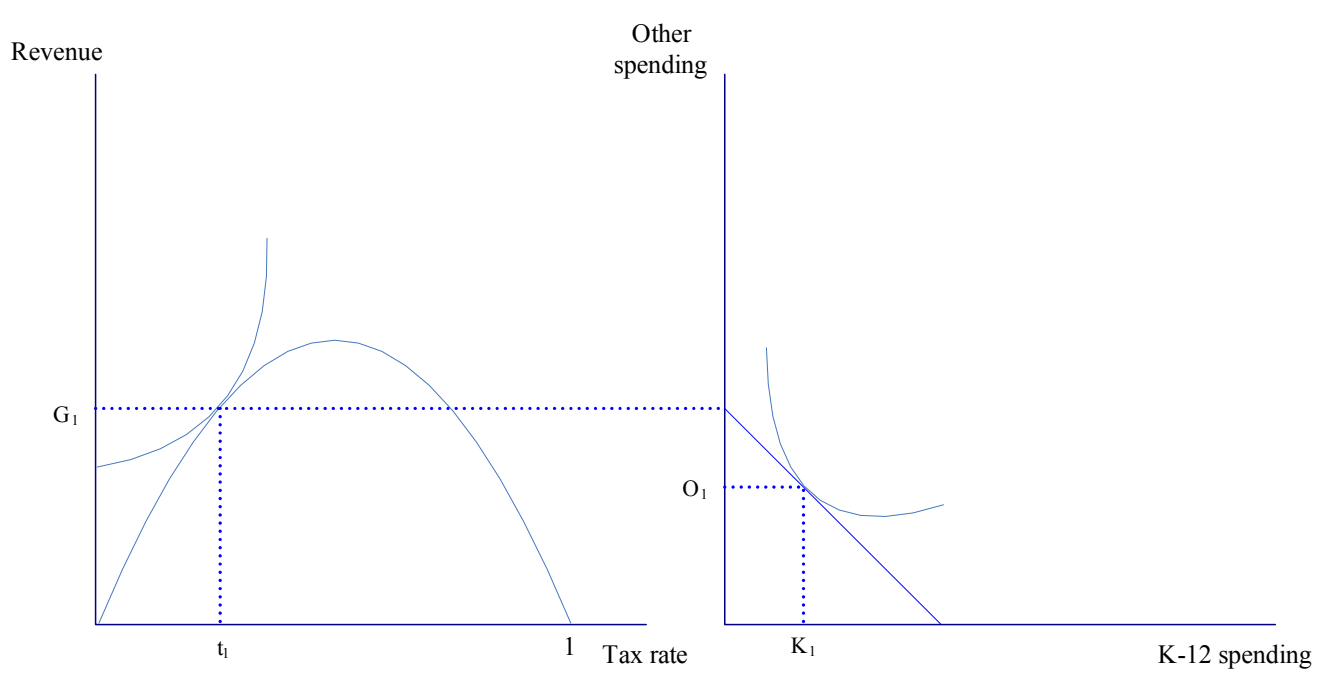

FIGURE 1. Optimal Legislative Spending Composition 


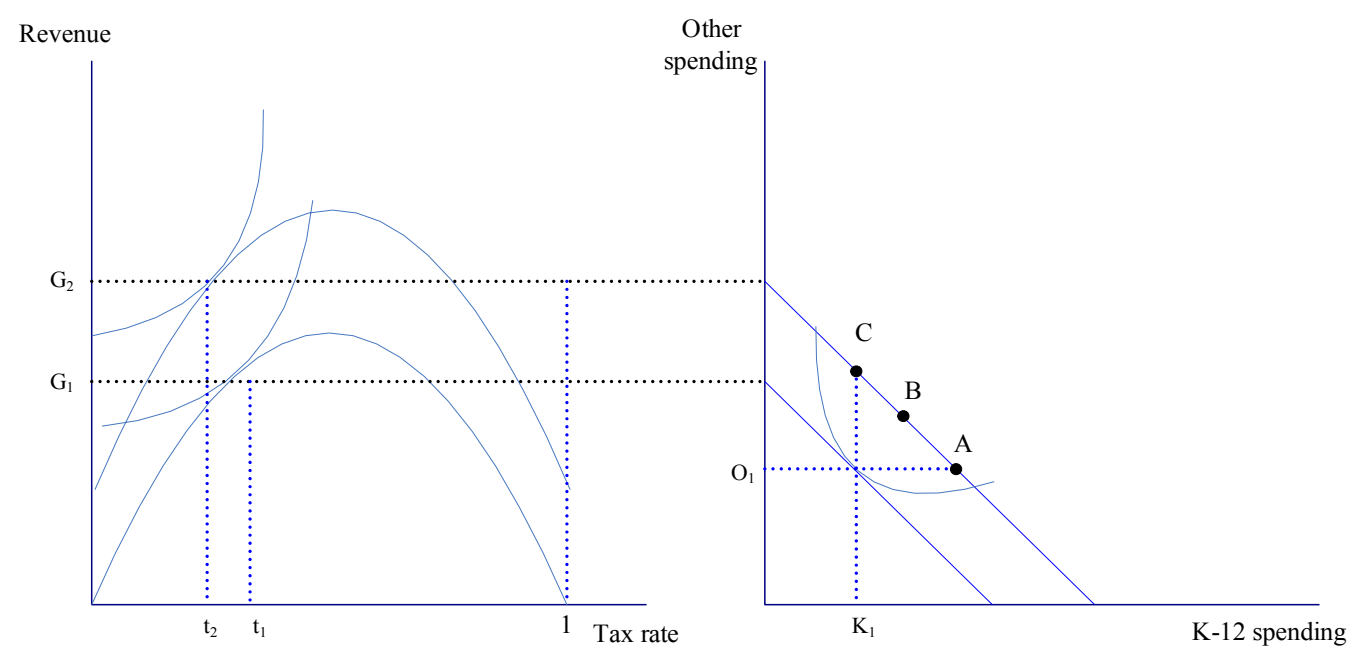

FIGURE 2. Impact of lottery on Optimal Spending

In Figure 2, adopting a lottery shifts the available dollars arc up by the amount of the net lottery proceeds (L). ${ }^{2}$ Legislators can now increase their voter support by raising spending to $G_{2}$ and cutting tax rates to $t_{2}$. Subsequently, the rise in government revenue pushes the budget constraint in the right-hand graph outward.

Note that we get exactly the same budget constraint shift no matter how the funds are earmarked. Whether the additional revenues are allocated to K-12 spending (point A), other spending (point C) or some mix (point B) depends solely on the shape of the political support indifference curves in the right-hand graphs. Unless earmarking changes the legislators' marginal rates of substitution, it should not impact the final distribution of spending.

${ }^{2}$ Our graph shows an increase in overall government revenue; a result that will be likely especially if the lottery attracts out-of-state consumers or stops in-state consumers from patronizing lotteries in neighboring states. However, this is not a necessary result or condition. Legislators might cut tax rates enough to counter an increase in lottery funds. Moreover, Borg, Mason, and Shapiro (1993); Fink, Marco, and Rork (2003); and others correctly note that lotteries will impact other sources of state tax revenues even if tax rates are unchanged. Sales and excise tax revenues are lost as consumers substitute lottery ticket purchases for other taxable goods and services; but income tax revenues rise, perhaps due to taxes on lottery winnings. However, because our study analyzes the impact of lotteries on the mix of spending, the size of the net increase or decrease in total funds available is not important. 
However, this might happen. Earmarking could impact these marginal rates of substitution in at least two ways. First, when funds are earmarked for K-12 education, legislators might decide that constituents will hold their political feet to the fire unless K-12 expenditures actually are increased. If so, earmarking will raise the marginal gain in political support from increased K-12 spending. This causes the legislative indifference curve in the right-hand graph of Figure 2 to become steeper and moves the equilibrium mix toward K-12 spending. In effect, earmarking funds for K-12 and expenditures for K12 are complementary goods.

On the other hand, in a world of asymmetric information and ill-informed voters, perception might matter more than reality. In other words, sometimes words can be a substitute for action. In this scenario, earmarking the proceeds for K-12 education might serve as a substitute for actual $\mathrm{K}-12$ spending. The public earmarking allows legislators to appear as if they favor K-12 education, regardless of their actual dollar commitment to the budget item. If this public posturing is enough for legislators to win the support of K12 advocates, they might feel less need to increase actual K-12 spending. In this case, earmarking lowers the marginal gain in political support from additional K-12 expenditures, flattens the legislative indifference curves, and tilts the equilibrium spending mix away from $\mathrm{K}-12$.

Does earmarking impact spending distributions? If so, how? Our empirical quest is to isolate the impact of lottery revenue on each spending area in states that earmark revenues compared to those that do not.

\section{SAMPLE STATES}

Currently, 42 states scattered throughout the U.S. operate lotteries; eight earmark all net lottery proceeds for K-12 education and another six add postsecondary education to their distribution lists. We used several criteria in determining our sample. First, we identified states whose lotteries had been in existence since 1990. Second, we selected geographically dispersed states that earmarked all of their lottery profits to K-12 education and yet bordered states that filtered their lottery profits into the general fund for distribution.

In total, we were able to identify five groups (see Table 1) that met our criteria: (1) New Hampshire and Maine (New England); (2) Ohio and Pennsylvania (Eastern Great Lakes); (3) Oregon and Washington (Pacific Northwest); (4) Illinois, Missouri, and Kansas (Great Plains); and (5) Michigan, Indiana, and Wisconsin (Western Great Lakes). In each set, the former state officially allocates lottery profit to K-12 education, ${ }^{3}$ while the latter deposits lottery profit into the general operating budget. Missouri moved its

\footnotetext{
${ }^{3}$ Oregon allocates 69 percent of its lottery profit to education. While, the state slightly varies from our qualifying criteria, it provides degrees of freedom from the Pacific Northwest region of the U.S.
} 
TABLE 1

Descriptive Statistics

\begin{tabular}{|c|c|c|c|c|c|c|c|c|}
\hline State & $\begin{array}{c}\text { Lottery } \\
\text { Inception } \\
\text { Date }\end{array}$ & $\begin{array}{l}\text { Lottery Profit } \\
\text { Distribution }\end{array}$ & $\begin{array}{l}\text { Per Capita } \\
\text { Income }\end{array}$ & $\begin{array}{l}\text { Per Pupil } \\
\text { Spending }\end{array}$ & $\begin{array}{l}\text { State Tax/ } \\
\text { Income }\end{array}$ & $\begin{array}{l}\text { Population } \\
\text { Enrolled in } \\
\text { K-12 (2001) }\end{array}$ & $\begin{array}{c}\text { Total } \\
\text { Education/ } \\
\text { Total State } \\
\text { Spending }\end{array}$ & $\begin{array}{c}\text { State } \% \text { of } \\
\text { K-12 } \\
\text { Spending } \\
(2001)\end{array}$ \\
\hline New Hampshire & 1964 & $100 \%$ K-12, 1967 & $\$ 33,969$ & $\$ 7,528$ & $2.87 \%$ & $16.43 \%$ & $19.7 \%$ & $52.7 \%$ \\
\hline Maine & 1974 & General Fund & $\$ 26,853$ & $\$ 8,531$ & $8.07 \%$ & $15.97 \%$ & $25.1 \%$ & $43.6 \%$ \\
\hline Ohio & 1974 & $100 \% \mathrm{~K}-12,1983$ & $\$ 28,699$ & $\$ 7,639$ & $6.00 \%$ & $16.10 \%$ & $30.0 \%$ & $51.4 \%$ \\
\hline Pennsylvania & 1971 & General Fund & $\$ 30,752$ & $\$ 8,525$ & $6.28 \%$ & $14.83 \%$ & $26.5 \%$ & $38.0 \%$ \\
\hline Washington & 1982 & $100 \% \mathrm{~K}-12,2001$ & $\$ 31,976$ & $\$ 7,200$ & $7.25 \%$ & $16.85 \%$ & $35.4 \%$ & $66.4 \%$ \\
\hline Oregon & 1985 & $69 \% \mathrm{~K}-12$ & $\$ 28,222$ & $\$ 8,593$ & $5.87 \%$ & $15.88 \%$ & $30.1 \%$ & $63.7 \%$ \\
\hline Illinois & 1974 & $100 \%$ K-12, 1985 & $\$ 32,655$ & $\$ 9,118$ & $5.46 \%$ & $16.60 \%$ & $28.3 \%$ & $42.4 \%$ \\
\hline Missouri & 1985 & $100 \%$ K-12, 1994 & $\$ 28,221$ & $\$ 6,524$ & $5.95 \%$ & $16.16 \%$ & $34.7 \%$ & $53.8 \%$ \\
\hline Kansas & 1987 & General Fund & $\$ 28,432$ & $\$ 7,355$ & $6.88 \%$ & $17.45 \%$ & $44.4 \%$ & $74.1 \%$ \\
\hline Michigan & 1972 & $100 \%$ K-12, 1982 & $\$ 29,629$ & $\$ 8,107$ & $8.08 \%$ & $17.32 \%$ & $41.8 \%$ & $71.3 \%$ \\
\hline Indiana & 1989 & General Fund & $\$ 27,522$ & $\$ 8,200$ & $6.55 \%$ & $16.30 \%$ & $38.5 \%$ & $49.5 \%$ \\
\hline Wisconsin & 1988 & General Fund & $\$ 29,196$ & $\$ 8,695$ & $6.76 \%$ & $16.28 \%$ & $34.1 \%$ & $59.7 \%$ \\
\hline
\end{tabular}


lottery revenue from the general fund to education in 1994, and Washington made the same switch in 2001.

Table 1 displays a variety of static demographic components for each state in the survey. Numerical data were either averaged over our 1984-2001 sample period or taken from 2001. The first two columns of Table 1 list the lottery inception date and the destination of the proceeds. All sample states allocated lottery profits either to K-12 education or to their general funds. The third and fourth columns of Table 1 contain the level of per capita income and per pupil spending in 2001. Within the groups, the higher income state spends more on education per pupil; New Hampshire and Oregon are the exceptions. Perpupil spending consistently tends to be lower in the lottery-for-education states.

Column five lists state tax revenue as a percent of income for 2001, and columns six and seven present the percentage of the population enrolled in public K-12 education and education spending as a percent of total state spending in 2001. There appears to be a positive correlation between the relative percentage of the population enrolled in public schools and the percent of state spending for those children. The last column lists the percent of state spending to total spending on K-12 education. All data were supplied by state and federal government sources.

\section{EMPIRICAL MODEL}

Our objective is to measure how the growth of lottery revenue impacts the composition of state spending over time and whether the results differ among states that do and do not earmark net lottery revenues to K-12 education. To address these issues, we isolate state spending on K-12 education, higher education, welfare, and highways.

First, similar to Fink, Marco, and Rork (2003) and Erekson et al. (1999), we pool the data for the states under consideration to estimate the model described by the equations below. One pool consists of states that earmark lottery revenue for K-12 education while the other consists of those that do not earmark lottery funds. We use a fixed-effects estimation for the model described below over the period 1984-2001.

Pooling across a wide range of states may mask differences in the characteristics of individual states as well as the behavior of the respective state legislatures. As a result, we next estimate the model by grouping states based on whether they earmark funds for education. For each set of states, we use the seemingly unrelated regressions estimation (SUR) technique to estimate the coefficients in equations 5 through 8 for each individual state over the 1984 to 2001 period. Under correct specification, this approach is more efficient than OLS, provides more state-specific details than a panel, yet it allows for a pooling of the data that increases the number of observations (Kennedy 1998). The SUR approach controls for correlated residual terms that may exist among the surveyed states. Furthermore, the SUR approach allows the coefficients of individual states to differ. 
The equations we estimate are:

$$
\begin{aligned}
& \mathrm{K}_{i t}=\alpha_{i}+\beta_{i} \mathrm{~K}_{i t-1}+\gamma_{i} \mathrm{REV}_{i t-1}+\delta_{i} \mathrm{LOT}_{i t-1}+\varepsilon_{i t} \\
& \mathrm{H}_{i t}=\alpha_{i}+\beta_{i} \mathrm{H}_{i t-1}+\gamma_{i} \mathrm{REV}_{i t-1}+\delta_{i} \mathrm{LOT}_{i t-1}+. \varepsilon_{i t} \\
& \mathrm{WF}_{i t}=\alpha_{i}+\beta_{i} \mathrm{WF}_{i t-1}+\gamma_{i} \mathrm{GSP}_{i t}+\delta_{i} \mathrm{LOT}_{i t-1}+. \varepsilon_{i t} \\
& \mathrm{R}_{i t}=\alpha_{i}+\beta_{i p} \beta_{i} \mathrm{R}_{i t-1}+\gamma_{i} \mathrm{REV}_{i t-1}+\delta_{i} \mathrm{LOT}_{i t-1}+. \varepsilon_{i t}
\end{aligned}
$$

$\mathrm{K}_{i t}$ is the growth rate of per-pupil K-12 state education spending for state $i$ in year $t$, and $\mathrm{K}_{i t-1}$ is its lag. Similarly, $\mathrm{H}$ is the growth rate of higher education spending, WF is spending growth on welfare, and $\mathrm{R}$ is spending growth on roads and highways. REV is the growth rate of state revenue, GSP is the two-period moving average of the growth rate of nominal GSP, and LOT is the two-period moving average of the state's annual lottery revenue growth rate. A two-period average was employed to ensure that the period for lottery and GSP (measured by calendar year) coincides with the other variables (measured by fiscal year). In each equation, $\beta$ represents the persistence in the dependent variable, $\gamma$ represents the elasticity of the dependent spending variable with respect to changes in state revenue, and $\delta$ represents the elasticity with respect to lottery revenue. Dummy variables were included when appropriate to account for changes in policy. For example, in 1995 the state of Michigan shifted education spending from the local level to the state level. This adjustment was accommodated by a reduction in local property taxes and an increase in the state sales tax.

In the case of discretionary spending (K-12 education, higher education, and highways), lagged revenue growth was used since states would likely choose spending levels based on the information available at the time the decision is made. Welfare spending tends to be nondiscretionary and sensitive to the state economy. Thus, contemporaneous state economic activity as measured by GSP was included in the model.

\section{EMPIRICAL RESULTS}

Detailed estimation results for each equation in the pooled model are reported in Table 2, while results for the state-specific model using SUR are reported in Table 3.

\subsection{Impact of Lottery Revenues}

The pooled estimates provide interesting results. In the pool of states that earmark lottery funds to K-12 education, the growth in lottery funds has no significant effect on the growth of state spending on K-12 education. However, the growth in lottery revenues does have a positive and significant effect on K-12 spending for those states that did not earmark the funds (significant at the 1 percent level). In other words, increased lottery revenues seem less likely to generate increased K-12 spending in "lottery-for-education" states than in "lottery-for-general-fund" states. 
The Review of Regional Studies, Vol. 37, No. 2, 2007, pp. 169 - 185

180

TABLE 2

Empirical Results for Pooled Regressions

\begin{tabular}{|c|c|c|c|}
\hline & & Earmark & General Fund \\
\hline \multirow[t]{3}{*}{ K-12 Ed. } & Lagged Spending & $\begin{array}{l}-0.14^{* * *} \\
(2.93)\end{array}$ & $\begin{array}{l}-0.38^{* * *} \\
(4.19)\end{array}$ \\
\hline & Lagged Revenue Growth & $\begin{array}{c}0.04 \\
(0.36)\end{array}$ & $\begin{array}{c}0.28^{* *} \\
(2.07)\end{array}$ \\
\hline & Lagged Lottery Growth & $\begin{array}{c}0.07 \\
(1.38)\end{array}$ & $\begin{array}{l}0.14^{* * *} \\
(4.42)\end{array}$ \\
\hline \multirow[t]{3}{*}{ Higher Ed. } & Lagged Spending & $\begin{array}{l}-0.23^{*} \\
(1.81)\end{array}$ & $\begin{array}{l}-0.25^{* * *} \\
(4.36)\end{array}$ \\
\hline & Lagged Revenue Growth & $\begin{array}{c}0.13^{*} \\
(1.92)\end{array}$ & $\begin{array}{c}0.21^{*} \\
(1.94)\end{array}$ \\
\hline & Lagged Lottery Growth & $\begin{array}{l}-0.01 \\
(0.49)\end{array}$ & $\begin{array}{r}0.003 \\
(0.17)\end{array}$ \\
\hline \multirow[t]{3}{*}{ Highways } & Lagged Spending & $\begin{array}{l}-0.33^{* * *} \\
(2.88)\end{array}$ & $\begin{array}{l}-0.30^{* *} \\
(2.30)\end{array}$ \\
\hline & Lagged Revenue Growth & $\begin{array}{l}-0.36 \\
(1.01)\end{array}$ & $\begin{array}{c}0.65^{* *} \\
(2.57)\end{array}$ \\
\hline & Lagged Lottery Growth & $\begin{array}{c}0.05 \\
(1.35)\end{array}$ & $\begin{array}{c}0.04 \\
(1.03)\end{array}$ \\
\hline \multirow[t]{3}{*}{ Welfare } & Lagged Spending & $\begin{array}{l}-0.05 \\
(1.48)\end{array}$ & $\begin{array}{l}0.36^{* * *} \\
(3.94)\end{array}$ \\
\hline & Growth in GSP & $\begin{array}{c}0.33 \\
(0.77)\end{array}$ & $\begin{array}{l}-0.60 \\
(1.57)\end{array}$ \\
\hline & Lagged Lottery Growth & $\begin{array}{c}0.03 \\
(1.20)\end{array}$ & $\begin{array}{l}-0.03 \\
(0.80)\end{array}$ \\
\hline
\end{tabular}

We find similar results using our second model. The growth in lottery revenues has a positive and significant effect on the growth of funding for K-12 education in five of the 12 states (New Hampshire, Maine, Pennsylvania, Kansas, and Wisconsin). As the pooled estimates suggested, this effect occurs almost exclusively among the states that do not earmark lottery revenues for education.

Among the six lottery-for-education states in our sample, we found a positive and significant link between the growth of lottery revenue and K-12 spending in only one (New Hampshire). On the other hand, a positive and significant impact does appear in four of the six states that did not earmark funds for K-12 (Kansas, Maine, Pennsylvania, and Wisconsin). At least in our sample of states, choosing to earmark seems to make it less likely that a growth in lottery revenues will increase the growth of actual K-12 funding. Legislators do not seem to view earmarking as a perfect substitute for actual funding; a growth in lottery revenues does have a positive, albeit insignificant, impact on 
TABLE 3

Empirical Results for State-Specific Regressions

\begin{tabular}{|c|c|c|c|c|c|c|}
\hline \multirow[b]{2}{*}{ State } & \multicolumn{3}{|c|}{ K-12 Education } & \multicolumn{3}{|c|}{ Higher Education } \\
\hline & Lag & Revenue & Lottery & Lag & Revenue & Lottery \\
\hline Illinois & $\begin{array}{l}-0.004 \\
(0.02)\end{array}$ & $\begin{array}{l}0.68^{* *} \\
(2.02)\end{array}$ & $\begin{array}{c}0.02 \\
(0.31)\end{array}$ & $\begin{array}{c}0.25 \\
(1.29)\end{array}$ & $\begin{array}{c}0.13 \\
(0.46)\end{array}$ & $\begin{array}{c}0.05 \\
(1.02)\end{array}$ \\
\hline Michigan & $\begin{array}{l}-0.16^{* * *} \\
(5.84)\end{array}$ & $\begin{array}{c}0.03 \\
(0.31)\end{array}$ & $\begin{array}{c}0.15 \\
(1.15)\end{array}$ & $\begin{array}{c}0.02 \\
(0.11)\end{array}$ & $\begin{array}{l}-0.07 \\
(0.48)\end{array}$ & $\begin{array}{l}0.26^{* *} \\
(2.08)\end{array}$ \\
\hline Missouri & $\begin{array}{l}-0.08 \\
(0.43)\end{array}$ & $\begin{array}{c}0.46 \\
(1.26)\end{array}$ & $\begin{array}{l}-0.04 \\
(0.41)\end{array}$ & $\begin{array}{c}0.43 \\
(1.57)\end{array}$ & $\begin{array}{l}0.43^{* * *} \\
(4.04)\end{array}$ & $\begin{array}{l}0.12^{* * *} \\
(3.68)\end{array}$ \\
\hline New & 0.16 & -0.02 & $0.18^{* * *}$ & -0.04 & $0.20^{* * *}$ & -0.03 \\
\hline Hampshire & $(1.00)$ & $(0.18)$ & $(3.18)$ & $(0.45)$ & (2.61) & $(0.77)$ \\
\hline Ohio & $\begin{array}{l}-0.19^{*} \\
(1.77)\end{array}$ & $\begin{array}{l}0.41^{* * *} \\
(3.92)\end{array}$ & $\begin{array}{c}0.03 \\
(0.99)\end{array}$ & $\begin{array}{l}-0.59^{* * *} \\
(5.09)\end{array}$ & $\begin{array}{l}-0.21 \\
(1.06)\end{array}$ & $\begin{array}{l}0.18^{* * *} \\
(3.02)\end{array}$ \\
\hline Oregon & $\begin{array}{l}-0.18^{*} \\
(1.63)\end{array}$ & $\begin{array}{l}0.45^{* * *} \\
(2.73)\end{array}$ & $\begin{array}{c}0.05 \\
(1.21)\end{array}$ & $\begin{array}{l}-0.09 \\
(0.34)\end{array}$ & $\begin{array}{c}0.12 \\
(0.52)\end{array}$ & $\begin{array}{l}-0.03 \\
(1.61)\end{array}$ \\
\hline Indiana & $\begin{array}{l}-0.74^{* * *} \\
(3.99)\end{array}$ & $0.79^{* * *}$ & $\begin{array}{c}0.02 \\
(0.13)\end{array}$ & $\begin{array}{l}-0.34^{*} \\
(1.66)\end{array}$ & $\begin{array}{l}-0.20 \\
(1.14)\end{array}$ & $\begin{array}{l}-0.21 \\
(1.11)\end{array}$ \\
\hline Kansas & $\begin{array}{l}-0.36^{* * *} \\
(3.79)\end{array}$ & $\begin{array}{l}0.62^{* * * *} \\
(5.10)\end{array}$ & $\begin{array}{c}0.41^{* * *} \\
(9.08)\end{array}$ & $\begin{array}{l}-0.18^{*} \\
(1.72)\end{array}$ & $\begin{array}{l}0.76^{* * *} \\
(3.11)\end{array}$ & $\begin{array}{l}-0.19^{* * *} \\
(2.73)\end{array}$ \\
\hline Maine & $\begin{array}{c}0.04 \\
(0.19)\end{array}$ & $\begin{array}{l}0.49^{* * *} \\
(2.58)\end{array}$ & $\begin{array}{c}0.05^{*} \\
(1.67)\end{array}$ & $\begin{array}{l}-0.27^{*} \\
(1.74)\end{array}$ & $\begin{array}{l}0.56^{* * *} \\
(3.51)\end{array}$ & $\begin{array}{l}-0.02 \\
(0.54)\end{array}$ \\
\hline Pennsylvania & $\begin{array}{l}-0.05 \\
(0.22)\end{array}$ & $\begin{array}{l}-0.54 \\
(1.26)\end{array}$ & $\begin{array}{l}0.19^{* *} \\
(2.30)\end{array}$ & $\begin{array}{l}-0.20^{* * *} \\
(2.62)\end{array}$ & $\begin{array}{l}-0.07 \\
(0.20)\end{array}$ & $\begin{array}{c}0.13^{*} \\
(1.89)\end{array}$ \\
\hline Washington & $\begin{array}{l}-0.28 \\
(1.21)\end{array}$ & $\begin{array}{c}0.23 \\
(0.63)\end{array}$ & $\begin{array}{c}0.10 \\
(0.85)\end{array}$ & $\begin{array}{l}-0.02 \\
(0.11)\end{array}$ & $\begin{array}{l}0.39^{* * *} \\
(1.98)\end{array}$ & $\begin{array}{l}0.05 \\
(0.63)\end{array}$ \\
\hline Wisconsin & $\begin{array}{l}-0.27^{* *} \\
(2.08)\end{array}$ & $\begin{array}{c}0.56^{*} \\
(1.88)\end{array}$ & $\begin{array}{l}0.12^{* * *} \\
(4.02)\end{array}$ & $\begin{array}{l}0.41^{* * *} \\
(3.02)\end{array}$ & $\begin{array}{c}0.34 \\
(1.47)\end{array}$ & $\begin{array}{c}0.01 \\
(1.24)\end{array}$ \\
\hline & & Welfare & & Roa & s and Higl & vays \\
\hline State & $\mathrm{Lag}$ & GSP & Lottery & $\mathrm{Lag}$ & Revenue & Lottery \\
\hline Illinois & $\begin{array}{l}0.29^{* * *} \\
(3.53)\end{array}$ & $\begin{array}{c}0.44 \\
(0.72)\end{array}$ & $\begin{array}{l}-0.03 \\
(0.96)\end{array}$ & $\begin{array}{l}-0.17 \\
(0.73)\end{array}$ & $\begin{array}{c}0.60 \\
(1.40)\end{array}$ & $\begin{array}{c}0.04 \\
(0.43)\end{array}$ \\
\hline Michigan & $\begin{array}{l}-0.33^{*} \\
(1.82)\end{array}$ & $\begin{array}{l}-0.02 \\
(0.04)\end{array}$ & $\begin{array}{l}-0.43^{* *} \\
(2.61)\end{array}$ & $\begin{array}{l}-0.14 \\
(0.89)\end{array}$ & $\begin{array}{c}0.02 \\
(0.17)\end{array}$ & $\begin{array}{l}-0.06 \\
(1.03)\end{array}$ \\
\hline Missouri & $\begin{array}{l}-0.23^{* * *} \\
(2.75)\end{array}$ & $\begin{array}{l}-0.75^{*} \\
(1.89)\end{array}$ & $\begin{array}{l}-0.01 \\
(0.20)\end{array}$ & $\begin{array}{l}-0.08 \\
(0.42)\end{array}$ & $\begin{array}{c}1.02^{*} \\
(1.83)\end{array}$ & $\begin{array}{c}0.06 \\
(0.33)\end{array}$ \\
\hline New & $-0.10^{* *}$ & $-0.75^{*}$ & 0.07 & -0.09 & $0.23^{* *}$ & 0.08 \\
\hline Hampshire & (2.19) & $(1.85)$ & (1.33) & $(0.62)$ & $(2.32)$ & (1.34) \\
\hline Ohio & $\begin{array}{c}0.06 \\
(0.35)\end{array}$ & $\begin{array}{l}-0.58 \\
(0.93)\end{array}$ & $\begin{array}{c}0.10 \\
(1.30)\end{array}$ & $\begin{array}{l}-0.17^{* *} \\
(1.97)\end{array}$ & $\begin{array}{l}-0.63^{* *} \\
(2.31)\end{array}$ & $\begin{array}{l}-0.05 \\
(0.76)\end{array}$ \\
\hline Oregon & $\begin{array}{c}0.17 \\
(0.95)\end{array}$ & $\begin{array}{l}-0.16 \\
(0.15)\end{array}$ & $\begin{array}{c}0.04 \\
(1.04)\end{array}$ & $\begin{array}{l}-0.48^{* *} \\
(2.36)\end{array}$ & $\begin{array}{l}-0.28 \\
(0.73)\end{array}$ & $\begin{array}{l}-0.02 \\
(0.30)\end{array}$ \\
\hline
\end{tabular}




\begin{tabular}{|c|c|c|c|c|c|c|}
\hline \multirow[b]{2}{*}{ State } & \multicolumn{3}{|c|}{ Welfare } & \multicolumn{3}{|c|}{ Roads and Highways } \\
\hline & Lag & GSP & Lottery & Lag & Revenue & Lottery \\
\hline \multirow[t]{2}{*}{ Indiana } & $0.37^{* * *}$ & 0.07 & 0.07 & $-0.20^{*}$ & $0.38^{* *}$ & -0.17 \\
\hline & $(4.57)$ & $(0.19)$ & $(0.55)$ & (1.90) & (2.79) & $(1.46)$ \\
\hline \multirow[t]{2}{*}{ Kansas } & 0.17 & $-2.92^{* * *}$ & $0.10^{*}$ & -0.11 & -0.22 & $0.25^{* *}$ \\
\hline & (1.47) & $(3.51)$ & $(1.78)$ & $(0.79)$ & $(0.58)$ & (1.96) \\
\hline \multirow[t]{2}{*}{ Maine } & 0.08 & $-1.18^{* *}$ & $0.09^{* *}$ & $0.37^{* *}$ & $0.86^{* *}$ & 0.002 \\
\hline & $(0.40)$ & $(2.34)$ & (1.91) & $(2.07)$ & $(2.52)$ & $(0.03)$ \\
\hline \multirow[t]{2}{*}{ Pennsylvania } & $-0.19^{* * * *}$ & $-2.74^{* * * *}$ & 0.10 & $0.06(0.52)$ & 0.19 & $0.38^{* *}$ \\
\hline & $(2.91)$ & (3.31) & $(1.29)$ & & (1.09) & $(2.54)$ \\
\hline \multirow[t]{2}{*}{ Washington } & $0.46^{* * *}$ & $0.80^{*}$ & 0.11 & $-0.58^{* * *}$ & $2.54^{* * *}$ & -0.36 \\
\hline & $(2.65)$ & $(1.75)$ & $(1.21)$ & (5.97) & (5.76) & $(1.49)$ \\
\hline \multirow[t]{2}{*}{ Wisconsin } & 0.24 & -0.44 & $-0.11^{* * *}$ & $-0.14^{*}$ & 0.23 & $0.05^{* *}$ \\
\hline & $(1.58)$ & $(0.58)$ & $(4.39)$ & $(1.94)$ & $(1.28)$ & $(2.09)$ \\
\hline
\end{tabular}

the growth of K-12 spending in almost every case. However, it seems clear that they do not consider earmarking a strong complement for such funding either.

If increased growth in lottery revenues did not show up as increased growth of K-12 spending, what happened to those dollars? The answer seems to vary. Among the five lottery-for-education states that did not have a significant relationship between the growth of lottery revenue and the growth of state K-12 spending, three had positive and significant relationships between the growth of lottery revenues and other forms of spending growth. Although Ohio, Michigan, and Missouri all earmark lottery funds for $\mathrm{K}-12$, the primary beneficiary in each of these states seems to have been higher education. Overall, the growth of lottery revenue had a positive and significant impact on the growth of some form of state spending in eight of the 12 states.

\subsection{Persistence}

The coefficients on lagged spending growth typically were negative. In the pooled regressions, the lagged coefficients are negative and significant in both pools for all three forms of discretionary spending (K-12 education, higher education, and highways). In the second, state-specific model, we found a negative relationship in 10 of the 12 states for K-12 education (significant in six), eight of the 12 for higher education (significant in five), and 10 of the 12 for highway spending (significant in five). This suggests negative persistence in both education and highway spending. Years of high growth in spending tend to be followed by years of low growth and vice-versa.

However, there was mixed evidence regarding the persistence of the growth of welfare spending. Positive persistence occurs in the sample of pooled states that did not earmark lottery funds. In eight of the 12 states (significant in three) in the state-specific model, however, negative persistence was found in four states (significant in three). 


\subsection{Impact of the Growth in Revenue and GSP}

In most cases, spending growth was positively related to revenue growth. In the pooled estimations, we found a positive and significant relationship for each discretionary spending category in the non-earmarking states and for higher education in lottery-foreducation states. In the state-specific model, revenue growth and spending growth are positively correlated in 10 of the 12 states for K-12 (significant in seven cases) and in eight of the 12 for higher education (significant in five cases). The impact of revenue growth on highway spending was similar to that of education: positive in nine of the 12 (significant in five). As expected, the growth of welfare spending was negatively related to the growth in GSP in nine states (significant in five), providing support for the countercyclical nature of welfare.

\section{SUMMARY AND CONCLUSION}

We extended the Stigler-Peltzman framework to examine how states spend lottery revenue and used an approach that enables us to investigate the impact of lotteries in a more controlled environment. As several other authors have found, lottery revenues are fungible. Earmarking the revenues for K-12 education does not necessarily cause an increase in actual state K-12 funding. The growth of lottery revenues had no effect on the growth of K-12 spending in our pooled sample of "lottery-for-education" states, nor did it have any significant impact in five of the six individual "lottery-for-education" states. Earmarking funds for education may serve to make lotteries more politically viable but has no practical impact on budget allocations.

Interestingly, lottery revenues seem more likely to boost K-12 spending in states that do not earmark the proceeds and deposit them directly into their general fund. The growth in lottery revenues had a positive and significant impact on the growth of K-12 funding in our pooled sample of "lottery-for-general-fund" states. It also had a positive and significant impact on K-12 spending in four of the six individual "lottery-for-generalfund" states. In other words, lotteries were less likely to benefit K-12 education in states that earmarked lottery funds for K-12 education than in those that did not.

While lotteries-for-education do not necessarily benefit their announced targets, they still can provide increased political support for legislators. Lottery revenues do spill over into other budgetary areas and raise the utility of constituents associated with those areas. In three of the states that earmarked proceeds for K-12 education, the main beneficiary was higher education.

The unanswered question is why legislators in these states apparently felt no significant pressure to follow through with their advertised aims. On the surface it seems that public pronouncements and actual decisions should be complementary products; the louder the public policy pronouncement becomes, the more important it is for legislators 
to follow through and enact the advertised policy if they are to maintain voter support. Yet it appears that this is not the case.

In a world of costly information and ill-informed voters, it is possible that by proclaiming that lottery revenues will benefit K-12 education, legislators can garner needed political capital from education supporters without having to significantly alter what they would have done anyway. While our results are consistent with this possibility, they certainly do not prove it. Consequently we checked for other explanations. Perhaps those states that earmarked had less pressing K-12 spending needs. However, because earmarking states tend to spend less per pupil than the non-earmarking states, this is not likely. Perhaps the results are skewed by differences in the relative importance of state versus local funding for education. But we could find no support for this possibility. Perhaps our results simply are a statistical anomaly. Future studies might shed additional light on this question.

\section{References}

Bolton, K.L., 2005. "N.C. lottery: How Did it Pass?” Asheville Citizen-Times, September 5, http://citizen-times.com/apps/pbcs.dll/article?AID=/20050905/ NEWS01/ 50904007/1009/RSS01\&theme=NCLOTTERY

Borg, M. and P.M. Mason, 1988. "The Budgetary Incidence of a Lottery to Support Education," National Tax Journal 41(1), 75-85. , 1990. "Earmarked Lottery Revenues: Positive Windfalls or Concealed Redistribution Mechanisms?" Journal of Education Finance 15(Winter), 289-301.

Borg, M., P. Mason, and S.L. Shapiro, 1993. "The Cross Effect of Lottery Taxes on Alternative State Tax," Public Finance Quarterly 21(2), 123-140.

Brinner, R.E. and C. Clotfelter, 1975. "An Economic Appraisal of State Lotteries," National Tax Journal 28(December), 95-104.

Campbell, N.D., 2003. "Do Lottery Funds Increase Educational Expenditure? Evidence from Georgia's Lottery for Education,"Journal of Education Finance 28(Winter), 383-402.

Caudill, Steven B., Jon M.Ford, Franklin G. Mixon Jr., and Ter Chao Peng, 1995. “A discrete-time hazard model of lottery adoption", Applied Economics, 27, 555-561.

Clotfelter, C.T. and P.J. Cook, 1990. "Redefining 'Success' in the State Lottery Business," Journal of Policy Analysis \& Management 9(1), 99(6).

Erekson, H.O., G. Platt, C. Whistler, and A. Kiegert, 1999. "Factors Influencing the Adoption of State Lotteries," Applied Economics 31, 875-884.

Erekson, H.O., K.M. Deshano, G. Platt, and A.L. Ziegert, 2002. "Fungibility of Lottery Revenues and Support of Public Education," Journal of Education Finance 28(Fall), 301-312.

Fink, S., A. Marco, and J.C. Rork, 2003. "The Impact of State Lotteries on State Tax Revenues," State Tax Notes 27(13), March 31.

Garrett, T.A., 2001. "Earmarked Lottery Revenues for Education: A New Test of Fungibility," Journal of Education Finance, 219-238. 
Garrett, T.A. and T.L. Marsh, 2002. "The Revenue Impacts of Cross-Border Lottery Shopping in the Presence of Spatial Autocorrelation," Regional Science and Urban Economics, 32(4), 501-519.

Hansen, A., A.D. Miyazaki, and D.E. Sprott, 2000. "The Tax Incidence of Lotteries from Five States," Journal of Consumer Affairs 34(2).

Hodges, J., 2001. South Carolina State of the Union Address, January 18.

Kennedy, P., 1998. A Guide to Econometrics, $4^{\text {th }}$ edition. MIT Press: Cambridge, MA.

Mikesell, J.L. and C.K. Zorn, 1986. "State Lotteries as Fiscal Savior or Fiscal Fraud: A Look at the Evidence," Public Administration Review, 311-320.

Novarro, N.K., 2005. "Earmarked Lottery Profits: A Good Bet for Education Finance?" Journal of Education Finance 31(1), 23-44.

Peltzman, S., 1976. "Toward a More General Theory of Regulation," The Journal of Law and Economics, 19 (August), 211-240.

Robertson, G.D., 2005. "Ex-New Mexico Chief To Head N.C. Lottery," Albuquerque Journal, November 17, www.abqjournal.com/news/apshaheen11-17-05.htm.

Rubenstein, Ross and Benjamin Scadafi 2002, "Who Pays and Who Benefits: Examining the Distributional Consequences of the Georgia Lottery for Education." National Tax Journal LV(2), 223-238.

Spindler, C., 1995. “The Lottery and Education: Robbing Peter to Pay Paul?” Public Budgeting and Finance 15(3), 54-62.

Stark, S.R., C. Wood, and D.S. Honeyman, 1993. "The Florida Education Lottery: Its Use as a Substitute for Existing Funds and Its Effects on the Equity of School Funding,"Journal of Education Finance 18(Winter), 231-242.

Stigler, G.J., 1971. "The Theory of Economic Regulation," Bell Journal of Economics and Management Science 2, 3-21.

Summers, S.R., D.S. Honeyman, J.L. Wattenbarger, and M.D. Miller, 1995. “An Examination of Supplantation and Redistribution Effects of Lottery Allocations to a Community College System,"Journal of Education Finance, 21(Fall), 236-253.

Spindler, C.J., 1995. "The Lottery and Education: Robbing Peter to Pay Paul," Public Budgeting \& Finance 15(3), 54-62.

Tosun, M.S. and M. Skidmore, 2004. "Interstate Competition and State Lottery Revenues," National Tax Journal LVII(2), Part 1, 163-178.

Vroman, D.H., 1976. “An Economic Analysis of the New York State Lottery,"National Tax Journal, 29(I4), 482-489.

\section{APPENDIX}

\section{Data Sources}

Lottery data were compiled from state lottery commissions. Population was taken from the Department of Commerce, Census Bureau. Industrial composition and personal income were from the Department of Commerce, Bureau of Economic Analysis. State tax data were obtained from U.S. Department of Commerce, State Government Finances. 